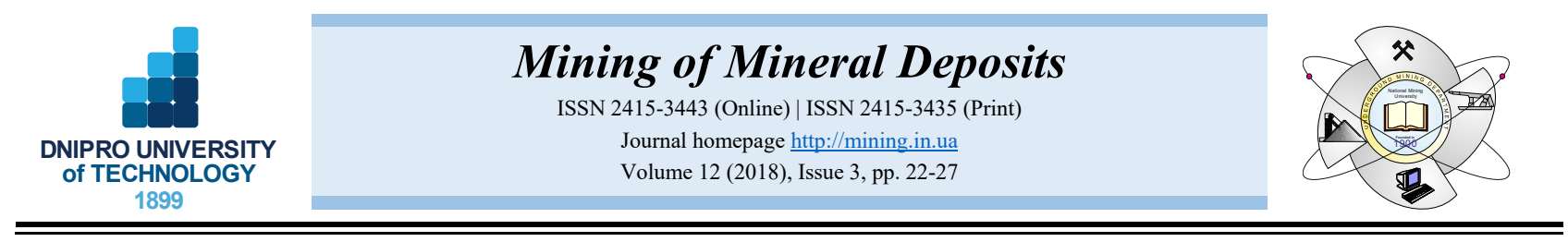

UDC 622.236

https://doi.org/10.15407/mining12.03.022

\title{
POWER CONSUMPTION OF ROCK DECOMPOSITION PROCESS DURING DIAMOND CORE DRILLING USING PULSE FLUSHING
}

\author{
A. Kozhevnykov ${ }^{1 *}$, A. Dreus ${ }^{2}$ \\ ${ }^{I}$ Dnipro University of Technology, Dnipro, Ukraine \\ ${ }^{2}$ Oles Honchar Dnipro National University, Dnipro, Ukraine \\ *Corresponding author: e-mail aak2@ua.fm, tel. +380562466346
}

\begin{abstract}
Purpose. To study the impact of pulse flushing on the power consumption of rock decomposition during diamond core drilling.

Methods. Theoretical analysis, processing of the obtained experimental data.

Findings. The decrease in power consumption of rock decomposition process during drilling with jet pulse flushing was studied. The influence of the bottom-hole power and jet pulse flushing parameters on the efficiency of rock decomposition process was investigated. Physical mechanisms of mining rock degradation under the jet pulse flushing were considered in the article.

Originality. It was established that the drilling performance is growing along with increasing of pauses between the flushing liquid supply intervals. At that, the relative reduction of energy consumption of the rock decomposition process is increasing when the bottom-hole power is decreasing. The study provides theoretical grounds for the increase in the mechanical rate of drilling during the jet pulse flushing owing to utilization of the generated frictional thermal energy in the bottom-hole. It is demonstrated that using pulse flushing intensifies the processes of thermal cycling degradation of the mining rock.

Practical implications. It is demonstrated that the pulse flushing mode has a potential to improve the performance of diamond core drilling. The outcomes of the research can be useful for grounding the specifications of the jet pulse flushing method during the development of the energy saving modes of diamond core drilling processes.
\end{abstract}

Keywords: diamond drilling, power consumption, flushing, thermal cycling impact

\section{INTRODUCTION}

Borehole drilling is one the most power consuming processes during exploration, survey and mining of mineral resources. It is important to understand the need to process deeper layers of mineral deposits at the current stage of the modern drilling methods development. This requires carrying out drilling works in hard and solid mining rocks located at very deep levels. Rotary diamond core drilling is the major method of drilling hard and solid rock formations. Nowadays, however, the conventional technologies of rotary drilling with time-constant mode parameters seem to have reached a certain limit of performance. Many researchers worldwide are eagerly looking for the possible ways to enhance the performance of the rotary diamond core drilling processes.

There are various approaches to solve this task. Many researchers, such as (Li et al., 2015), use surfactants to treat the bottom-hole surface during drilling. These sub- stances make it possible to decrease the surface energy of the rock and increase the mechanical rate of drilling. Another approach to enhance the drilling performance is implemented in the techniques which combine the rotary drilling with some other ways of drilling. For instance, it is possible to rise the mechanical rate of drilling in hard and solid rocks by using the mechanical specific energy of the boring tool and hydraulic power of the flushing liquid (Mohan, Adil, \& Samuel, 2014), the combined use of mechanical and electrical impacts on the rock (Vazhov, Datskevich, Zhurkov, Muratov, \& Jeffryes, 2017), combining of percussion boring and rotary drilling (Kondratenko, Timonin, \& Patutin, 2016; Zha et al., 2017) etc.

One of the most promising techniques to enhance the performance of deep holes drilling is the combined use of mechanical and heating impacts (Rauenzahn \& Tester, 1989; Rossi, Kant, von Rohr, \& Saar, 2017). These techniques are known as thermomechanical methods. High temperature jets are most commonly used as the source

(C) 2018. A. Kozhevnykov, A. Dreus. Published by the Dnipro University of Technology on behalf of Mining of Mineral Deposits.

This is an Open Access article distributed under the terms of the Creative Commons Attribution License (http://creativecommons.org/licenses/by/4.0/),

which permits unrestricted reuse, distribution, and reproduction in any medium, provided the original work is properly cited. 
of thermal energy in thermomechanical methods. At the same time, friction heat generated on the bottom-hole surface is the source of thermal energy in the traditional diamond core drilling. It is widely known that only a minor fraction of power generated in the bottom hole area is utilized for rock decomposition (Simon, 1963). The main portion of the mechanical power (up to $98 \%$ ) is transferred into the thermal power during bottom-hole drilling. Thus generated thermal power may be utilized as a reserve which is capable to increase the efficiency of rock decomposition in conventional rotary drilling.

It is possible to use thermal factor for rock decomposition by switching the bottom-hole flushing mode to the pulse mode. Various physical effects related to the changes in hydraulic dynamics during pulse flushing were in detail discussed earlier (Dreus, Lysenko, Kozhevnykov, \& Liu, 2017). The outcomes of the conducted research (Dreus, Kozhevnikov, Lysenko, \& Sudakov, 2016) testify that the pulse flushing mode allows to increase the contact temperature and enhance the rate of drilling. On the one hand, change in the temperature mode during the pulse flushing enhances thermomechanical impact on the rock. On the other hand, such thermal cycling impact results in the growth of rock brittleness. The combined action of the said factors leads to reduction in power consumption during rock decomposition process. However, the correlation of the achieved effects has not been properly studied until now and, therefore, requires further examination. The article deals with the outcomes of the research and analysis of the rock decomposition process using the pulse flushing mode during borehole drilling.

\section{EXPERIMENTAL STUDY}

The research into drilling borehole pulse flushing technique, in particular, the interrupted flushing, was carried out at National Mining University (Dnipro University of Technology, Dnipro, Ukraine). The interrupted flushing is characterized by the phase of pause in the flushing liquid supply. Therefore, the flushing liquid flow in the hydraulic system of the drill bit is halted during the pause, thus bringing the convective heat exchange down to zero. It allows to rise the contact temperature to the values which can be limited only by the heat resistance of boring tools. To characterize pulse flushing mode, we have introduced the intermittency factor $k_{\text {int }}$ which can be determined as a ratio:

$$
k_{\text {int }}=\frac{\tau_{\text {pause }}}{\tau_{\text {flow }}},
$$

where:

$\tau_{\text {pause }}$ - pause duration;

$\tau_{\text {flow }}$ - fluid feed duration.

Drilling has been performed with a single-layer diamond core of 01A3 type, $59 \mathrm{~mm}$ diameter, with four flushing channels (Fig. 1). Drilling was performed on a granite block of IX drillability category. Water was used as drilling fluid. ZIF-300 Rig equipped with auxiliary gear box together with NB-3 drilling pump are the main test bench components. EMR-2 flowmeter was used additionally for recording and control of drilling conditions. General view of test bench is presented in Figure 2.

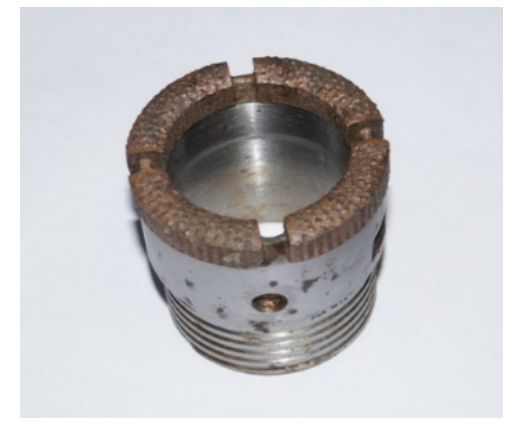

Figure 1. Diamond drilling core of 01 A3 type

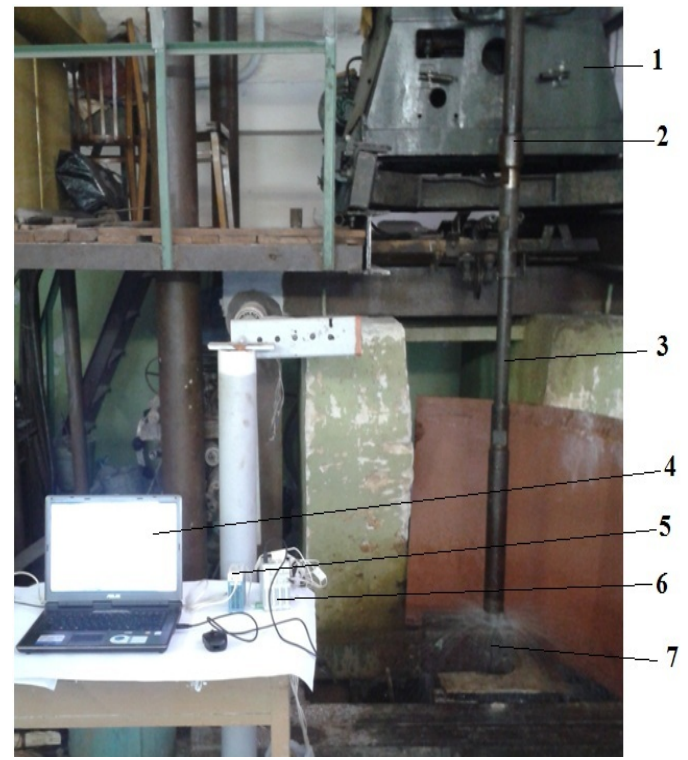

Figure 2. Test bench general view: 1 -rock drilling machine ZIF-300; 2 -kelly stem; 3 -drilling tool; 4 - computer; 5-power supply unit; 6-electronic interface; 7 -granite block

Flushing mode was changed during drilling with 01A3 core bit. Drilling was done in continuous flushing mode with the intermittency factor $k_{\text {int }}=0$, and in intermittent flushing mode with intermittency factor values of $k_{\text {int }}=0.2$ and $k_{\text {int }}=1$. Drilling was conducted at different rotation speed and axial load values.

\section{RESULTS AND DISCUSSION}

The mechanical rate of drilling under various modes of flushing was determined in the experiments. To evaluate the drilling performance in pulse flushing mode as compared to the drilling with time-constant flushing, we use the efficiency ratio between the mechanical rates of drilling:

$$
K_{\text {eff }}=\frac{V^{\text {pulse }}}{V^{\text {const }}},
$$

where:

$V^{p u l s e}$ - mechanical rate of drilling in pulse flushing mode;

$V^{\text {const }}$ - mechanical rate of drilling in constant flushing mode.

The mechanical rate of drilling is defined by the widely known formula: 
$V=\frac{N}{A S}$,

where:

$N$ - bottom-hole efficiency;

$S$ - bottom-hole surface area;

$A$-power intensity of the rock decomposition in the pulse and constant flushing modes, respectively.

The rate of drilling under the constant and pulse flushing shall be determined as:

$$
V^{\text {const }}=\frac{N^{\text {const }}}{A^{\text {const }} \cdot S^{\text {const }}} ; \quad V^{\text {pulse }}=\frac{N^{\text {pulse }}}{A^{\text {pulse }} \cdot S^{\text {pulse }}} .
$$

Based upon the (2) and (4), under the same values of bottom-hole efficiency $N^{\text {pulse }}=N^{\text {const }}$ and equal figures for down-hole surface areas $S^{\text {pulse }}=S^{\text {const }}$, the increase in the mechanical rate of drilling seems possible to achieve only by reduction of power consumption related to rock decomposition process:

$$
K_{\text {eff }}=\frac{A^{\text {const }}}{\left(A^{\text {const }}-\Delta A\right)}=\left(1-\frac{\Delta A}{A^{\text {const }}}\right)^{-1},
$$

where:

$\Delta A$ - reduction of rock decomposition power consumption due to transfer to pulse flushing mode.

From (2) and (5), it follows that:

$$
\Delta A=A^{\text {const }}\left(1-\frac{1}{K_{e f f}}\right)^{-1} \text {. }
$$

Table 1 lists the results of calculations of the ratio $K_{\text {eff }}$ and decrease in the rock decomposition process power consumption during granite drilling based on the experimental data.

Table 1. Reduction of power consumption of the rock decomposition process during drilling in pulse flushing mode

\begin{tabular}{cccccc}
\hline \multirow{2}{*}{$N, \mathrm{~kW}$} & \multirow{2}{*}{$k_{\text {int }}$} & \multirow{2}{*}{$K_{\text {eff }}$} & \multirow{2}{*}{$A^{\text {const }}, \mathrm{kJ} / \mathrm{m}^{3}$} & \multicolumn{2}{c}{$\Delta A$} \\
\cline { 5 - 6 } 1.7 & 1.0 & 2.20 & \multirow{2}{*}{$4880 \cdot 10^{3}$} & $2660 \cdot 10^{3}$ & 54.5 \\
& 0.2 & 2.00 & & $2440 \cdot 10^{3}$ & 50.0 \\
\multirow{2}{*}{3.4} & 1.0 & 1.45 & \multirow{2}{*}{$1850 \cdot 10^{3}$} & $583 \cdot 10^{3}$ & 31.5 \\
& 0.2 & 1.18 & & $282 \cdot 10^{3}$ & 15.3 \\
\hline
\end{tabular}

As evident from the data in Table 1, the pulse flushing mode allowed decreasing of power consumption by rock decomposition process within the range from 15.3 to $54.5 \%$. The decomposition power consumption decreases along with the increase in the bottom-hole efficiency both in constant flushing and pulse flushing modes.

It should be noted that a greater relative reduction of the power consumption by the rock decomposition process was revealed for the lower level of the bottom-hole power. This fact is a clear evidence that the pulse flushing mode has a potential for further increase in drilling performance in conditions of deteriorating bottom-hole efficiency, in particular, during deep drilling. According to the data presented in Figure 3, the reduction of power consumption also depends on the flushing liquid intermittency factor.

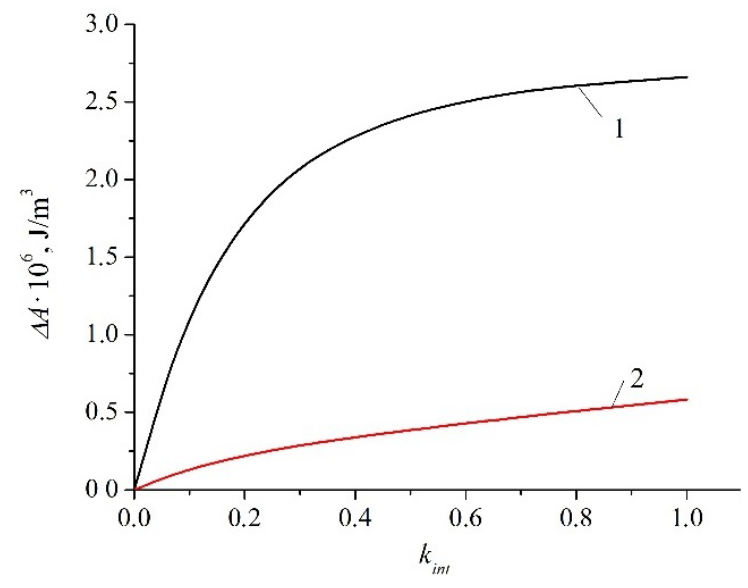

Figure 3. Reduction of granite decomposition power consumption $\Delta A$ correlation with the flushing liquid intermittency factor at the bottom-hole power level $N 1.7 \mathrm{~kW}$ (1) and $3.4 \mathrm{~kW}(2)$

Hence, the increase in the decomposition process performance during the pulse flushing is ensured not only by the mechanical power gain. Flushing mode with intermittency factor $k_{\text {int }}=1.0$ ensures more significant gain of the mechanical rate of drilling than for $k_{\text {int }}=0.2$. It can be explained by longer pause, which results in more substantial heating of the rock so that the power balance is redistributed on the bottom-hole area. The additional heat power is the factor that ensures the reduction of the power consumption by rock decomposition process.

There are several reasons causing power consumption reduction during rock decomposition process when the contact temperature of drilling is growing. Various physical effects are known to take place in rocks under high temperatures (Zhang, Sun, Hao, Geng, \& Lv, 2016), such as change in mechanical properties, structure, waves propagation speed etc. The analysis of geomechanical processes while drilling (Mishnaevsky, 1995) reveals that the impact on the subsurface cracks is the most efficient method to reduce the power consumption of rock decomposition process.

When drilling in pulse flushing mode, such impact can be ensured by increasing the difference between the contact temperature and the temperature of flushing liquid. Rotation of the drilling tool creates the thermal cycling effect. The research (Dreus, Sudakov, Kozhevnykov, \& Vakhalin, 2016) demonstrates that due to the temperature drop from $T_{h}$ to $T_{c}$, the tensile stresses emerge in the parallel surfaces of the bottom-hole area:

$\sigma_{*}=-\frac{E \beta\left(T_{h}-T_{c}\right)}{1-\mu}$,

where:

$E$ - Young's module of the rock;

$\beta$-coefficient of the rock linear expansion;

$\mu$ - Poisson ratio of the rock.

The minimum length of the crack $l_{\min }$, which opens by the said tensile strength, can be found from the Griffith's energy fracture criterion:

$\sigma_{*}=\frac{K \sqrt{2}}{\pi \sqrt{l_{\min }}}$, 
where:

$K$ - constant of the material.

The cracks with $l>l_{\text {min }}$ length can turn into changeable state under the said stress. To achieve this condition, it is necessary that the cooling time should exceed the certain value $\tau_{\min }$ - delay time. The following formula can be used to determine the delay time in case of intensive cooling (Moskalyov, Pigida, Kerekelitsa, \& Vakhalin, 1987):

$$
\tau_{\min }=\frac{4}{a \pi^{3}} \cdot \frac{l^{3}}{\left(\sqrt{\frac{l_{\min }}{l}}-1\right)^{2}},
$$

where:

$l$ - length of the crack;

$a$ - mining rock temperature diffusivity coefficient.

In order to carry out the quantitative estimation of rocks susceptibility to decomposition under the thermal cyclic impact, the criterion called resistivity to thermal cyclic decomposition is used herein (Moskalyov, Pigida, Kerekelitsa, \& Vakhalin, 1987):

$$
H=2.39 \frac{1}{a}\left(\frac{\gamma}{E}\right)^{2} \cdot\left(\frac{1-\mu}{\beta}\right)^{4} \text {. }
$$

Let us consider the performance of thermal cyclic degradation in the course of diamond core drilling of various mining rocks whose particular features are presented in Table 2 below.

Table 2. Physical-mechanical and thermophysical parameters of rocks

\begin{tabular}{lcccccc}
\hline Rock & $\begin{array}{r}E \cdot 10^{10}, \\
\mathrm{~N} / \mathrm{m}^{2}\end{array}$ & $\begin{array}{c}\beta 10^{5}, \\
\mathrm{~K}^{-1}\end{array}$ & $\mu$ & $\begin{array}{c}K \cdot 10^{6}, \\
\mathrm{~N} / \mathrm{m}^{3 / 2}\end{array}$ & $\begin{array}{c}\lambda, \\
\mathrm{W} / \\
(\mathrm{m} \cdot \mathrm{K})\end{array}$ & $\begin{array}{c}a \cdot 10^{6}, \\
\mathrm{~m}^{2} / \mathrm{s}\end{array}$ \\
\hline $\begin{array}{l}\text { Granite } \\
\text { Ferrous }\end{array}$ & 2.9 & 1 & 0.10 & 1.70 & 2.40 & 0.89 \\
$\begin{array}{l}\text { quartzite } \\
\begin{array}{l}\text { Sand- } \\
\text { stone }\end{array}\end{array}$ & 6.7 & 1.35 & 0.21 & 3.20 & 2.85 & 1.70 \\
Diorite & 7.9 & 0.25 & 0.28 & 2.37 & 1.80 & 1.22 \\
\hline
\end{tabular}

Table 3 represents the results of rocks degradation under the temperature gradient on the bottom-hole surface of $600^{\circ} \mathrm{C}$. It corresponds to the conditions of diamond core drilling process. Considering that the time of cooling in rotary drilling is very short, it becomes obvious that the less delay time, the more beneficial conditions are ensured to utilize the thermal cycling effect.

Table 3. Mining rocks thermal cycling degradation parameters while drilling in pulse flushing mode

\begin{tabular}{lccc}
\hline \multicolumn{1}{c}{ Rock } & $l_{\min }, \mathrm{mm}$ & $\tau_{\min }, \mathrm{s}$ & $N, \mathrm{~s} \cdot \mathrm{K}^{4}$ \\
\hline Granite & 0.035 & 0.001 & $2.75 \cdot 10^{7}$ \\
Ferrous & 0.070 & 0.004 & $1.07 \cdot 10^{7}$ \\
quartzite & 0.100 & 0.990 & $1.32 \cdot 10^{11}$ \\
Sandstone & 0.007 & 0.0003 & $1.53 \cdot 10^{6}$ \\
Diorite & 0.0 \\
\hline
\end{tabular}

The obtained results testify that the performance of thermal cycling degradation is not the same for different rock formations. The rocks with high $H$ values can soften only under continuous cooling of the bottom-hole surface. For example, the sandstone the thermal cycling effect will be less pronounced. The demonstrated results are confirmed by the experimental research (Zhang et al., 2017) which established that during rotary drilling of the sandstone, the difference of temperatures between the rock and cooling liquid shall not ensure any increase in the drilling speed.

Processes with short-term temperature drops can be applied to the rocks with relatively small values of $N$. For example, initial cracks of small length are required for the efficient degradation of diorite, while the decomposition process delay time comprises only a few milliseconds, which can be achieved during diamond core drilling.

\section{CONCLUSIONS}

Application of the pulse flushing mode makes it possible to achieve the reduction of power consumption of rocks decomposition process and to increase the mechanical speed of diamond core drilling process.

When the pulse flushing mode is used, the values of relative reduction of the rock decomposition process are higher at the lower levels of bottom-hole power. The pulse flushing mode, therefore, seems to have a great potential for enhancing both the performance of deep drilling and in the conditions where it is impossible to ensure high levels of bottom-hole power.

Mining rocks decomposition under the pulse flushing mode has a dual mechanism. On the one hand, the contact temperature is rising along with thermal degradation of the rock. On the other hand, the process of the rock cracking is intensified due to the thermal cycling effect.

The efficiency of thermal cycling impact during diamond core drilling with pulse flushing mode depends on the physical and mechanical properties of the rock.

\section{ACKNOWLEDGEMENTS}

The present study was based on the results of the experimental research into the process of diamond core drilling in pulse flushing mode within the frames of projects implemented by the Department of Deposits Prospecting Technique at the National Mining University (Dnipro University of Technology, Dnipro, Ukraine). The authors hereby express their gratitude to all colleagues at the Department of Deposits Prospecting Technique who took part in the experimental research.

\section{REFERENCES}

Dreus, A., Kozhevnikov, A., Lysenko, K., \& Sudakov, A. (2016). Investigation of heating of the drilling bits and definition of the energy efficient drilling modes. Eastern-European Journal of Enterprise Technologies, 3(7(81)), 41-46. https://doi.org/10.15587/1729-4061.2016.71995

Dreus, A.Yu., Sudakov, A.K., Kozhevnykov, A.A., \& Vakhalin, Yu.N. (2016). Study on thermal strength reduction of rock formation in the diamond core drilling process using pulse flushing mode. Naukovyi Visnyk Natsionalnoho Hirnychoho Universytetu, (3), 5-10.

Dreus, A., Lysenko, K., Kozhevnykov, A., \& Liu, B. (2017). Modeling hydrodynamics of the flushing fluid intermittent flow in the hydraulic system of the diamond bit. Mining of Mineral Deposits, 11(2), 84-90. https://doi.org/10.15407/mining11.02.084 
Kondratenko, A.S., Timonin, V.V., \& Patutin, A.V. (2016). Prospects for directional drilling in hard rocks. Journal of Mining Science, 52(1), 129-134. https://doi.org/10.1134/s1062739116010212

Li, W., Zhao, X., Li, Y., Ji, Y., Peng, H., Liu, L., \& Yang, Q. (2015). Laboratory investigations on the effects of surfactants on rate of penetration in rotary diamond drilling. Journal of Petroleum Science and Engineering, (134), 114-122. https://doi.org/10.1016/j.petrol.2015.07.027

Mishnaevsky, L.L. (1995). Physical mechanisms of hard rock fragmentation under mechanical loading: a review. International Journal of Rock Mechanics and Mining Sciences \& Geomechanics Abstracts, 32(8), 763-766. https://doi.org/10.1016/0148-9062(95)00027-e

Mohan, K., Adil, F., \& Samuel, R. (2014). Comprehensive hydromechanical specific energy calculation for drilling efficiency. Journal of Energy Resources Technology, 137(1), 012904. https://doi.org/10.1115/1.4028272

Moskalyov, A.N., Pigida, Ye.Yu., Kerekelitsa, L.G., \& Vakhalin, Yu.N. (1987). Razrushenie gornyh porod pri termocyclicheskom vozdeistvii. Kyiv: Naukova dumka.

Rauenzahn, R.M., \& Tester, J.W. (1989). Rock failure mechanisms of flame-jet thermal spallation drilling - theory and experimental testing. International Journal of Rock Mechanics and Mining Sciences \& Geomechanics Abstracts, 26(5), 381-399. https://doi.org/10.1016/0148-9062(89)90935-2

Rossi, E., Kant, M.A., von Rohr, P.R., \& Saar, M.O. (2017). Combining conventional and thermal drilling in order to increase speed and reduce costs of drilling operations to access deep geothermal resources. EGU General Assembly Conference Abstracts, (19), 13566.

Simon, R. (1963). Energy balance in rock drilling. Society of Petroleum Engineers Journal, 3(04), 298-306. https://doi.org/10.2118/499-pa

Vazhov, V.F., Datskevich, S.Y., Zhurkov, M.Y., Muratov, V.M., \& Jeffryes, B. (2017). Discharge-mechanical method of rock breakage. Journal of Physics: Conference Series, (830), 012148.

https://doi.org/10.1088/1742-6596/830/1/012148

Zha, C., Liu, G., Li, J., Li, Y., Xi, Y., \& Guo, B. (2017). Combined percussive-rotary drilling to increase rate of penetration and life of drill bit in drilling hard rock formation. Chemistry and Technology of Fuels and Oils, 53(2), 254-262. https://doi.org/10.1007/s10553-017-0802-x

Zhang, W., Sun, Q., Hao, S., Geng, J., \& Lv, C. (2016). Experimental study on the variation of physical and mechanical properties of rock after high temperature treatment. Applied Thermal Engineering, (98), 1297-1304. https://doi.org/10.1016/j.applthermaleng.2016.01.010

Zhang, W., Li, G., Huang, Z., Song, X., Mao, S., Dai, X., Guo, Zh., \& Cheng, Z. (2017). Effects of fluid medium and temperature on bit-rock interaction parameters of hard sandstone drilling. American Rock Mechanics Association. In $51^{\text {st }}$ U.S. Rock Mechanics/Geomechanics Symposium. San Francisco, California, USA.

\section{ЕНЕРГОСМНІСТЬ ПРОЦЕСУ РУЙНУВАННЯ ГІРСЬКИХ ПОРІД ПРИ АЛМАЗНОМУ БУРІННІ 3 ІМПУЛЬСНИМ ПРОМИВАННЯМ}

\section{А. Кожевников, А. Дреус}

Мета. Дослідження впливу імпульсного режиму промивання на енергоємність процесу руйнування гірської породи при алмазному бурінні.

Методика. Буріння здійснювалось по блоку граніту IX категорії за буримістю. Для проведення досліджень використано експериментальний стенд, що складається з бурового верстата ЗІФ-300 з додатковою коробкою передач і бурового насоса НБ-3. Для реєстрації та контролю режимних параметрів буріння використано витратомір ЕМР-2. В якості промивної рідини використовувалась вода. Буріння здійснювалося одношаровою алмазною коронкою $01 \mathrm{~A} 3$ діаметром 59 мм з чотирма промивальним каналами.

Результати. Визначено механічну швидкість буріння при різних видах промивання. Дано теоретичне обгрунтування збільшенню механічної швидкості буріння при імпульсному промиванні за рахунок використання теплової енергії тертя у вибої, що генерується. Встановлено, що збільшення механічної швидкості буріння можливо лише за рахунок зниження енергоємності процесу руйнування гірської породи. Досягнуто зниження енергоємності процесу руйнування породи при бурінні з імпульсним промиванням на 15.0 - 54.5\%, при цьому 3 підвищенням рівня вибійної потужності енергоємність руйнування знижується як у випадку постійного промивання, так і в разі імпульсного. Встановлено, що ефективність термоциклічного впливу при алмазному бурінні 3 імпульсним промиванням залежить від фізико-механічних властивостей гірської породи.

Наукова новизна. Виявлено, що ефективність процесу буріння зростає зі збільшенням паузи в подачі промивної рідини, при цьому відносне зниження енергоємності руйнування гірської породи збільшується при зменшенні рівня вибійної потужності.

Практична значимість. Імпульсне промивання $є$ резервом підвищення ефективності алмазного буріння. Результати дослідження представляють інтерес для обгрунтування параметрів технології імпульсного промивання при розробці енергоефективних режимів алмазного буріння.

Ключові слова: алмазне буріння, гірські породи, енергоємність, промивка, термочиклічний вплив

\section{ЭНЕРГОЕМКОСТЬ ПРОЦЕССА РАЗРУШЕНИЯ ГОРНЫХ ПОРОД ПРИ АЛМАЗНОМ БУРЕНИИ С ИМПУЛЬСНОЙ ПРОМЫВКОЙ}

\section{А. Кожевников, А. Дреус}

Цель. Исследование влияния импульсного режима промывки на энергоемкость процесса разрушения горной породы при алмазном бурении.

Методика. Бурение выполнялось по блоку гранита IX категории по буримости. Для проведения исследований использован экспериментальный стенд, состоящий из бурового станка ЗИФ-300 с дополнительной короб- 
кой передач и бурового насоса НБ-3. Для регистрации и контроля режимных параметров бурения использован расходомер ЭМР-2. В качестве промывочной жидкости использовалась вода. Бурение осуществлялось однослойной алмазной коронкой 01А3 диаметром 59 мм с четырьмя промывочными каналами.

Результаты. Определена механическая скорость бурения при разных видах промывки. Дано теоретическое обоснование увеличения механической скорости бурения при импульсной промывке за счет использования генерируемой тепловой энергии трения в забое. Установлено, что увеличение механической скорости бурения возможно только за счет снижения энергоемкости процесса разрушения горной породы. Достигнуто снижение энергоемкости процесса разрушения породы при бурении с импульсной промывкой на $15.0-54.5 \%$, при этом с повышением уровня забойной мощности энергоемкость разрушения снижается как в случае постоянной промывки, так и в случае импульсной промывки. Установлено, что эффективность термоциклического воздействия при алмазном бурении с импульсной промывкой зависит от физико-механических свойств горной породы.

Научная новизна. Выявлено, что эффективность процесса бурения возрастает с увеличением паузы в подаче промывочной жидкости, при этом относительное снижение энергоемкости разрушения горной породы увеличивается при уменьшении уровня забойной мощности.

Практическая значимость. Импульсная промывка является резервом повышения эффективности алмазного бурения. Результаты исследования представляют интерес для обоснования параметров технологии импульсной промывки при разработке энергоэффективных режимов алмазного бурения.

Ключевые слова: алмазное бурение, горные породы, энергоемкость, промывка, термочиклическое воздействие

\section{ARTICLE INFO}

Received: 6 March 2018

Accepted: 27 June 2018

Available online: 20 July 2018

\section{ABOUT AUTHORS}

Anatolii Kozhevnykov, Doctor of Technical Sciences, Professor of the Techniques Prospect of Deposits Department, Dnipro University of Technology, 19 Yavornytskoho Ave., 49005, Dnipro, Ukraine. E-mail: aak2@ua.fm

Andrii Dreus, Candidate of Technical Sciences, Associate Professor of the Fluid Mechanics and Energy \& Mass Transfer Department, Oles Honchar Dnipro National University, 72 Haharina Ave., 49010, Dnipro, Ukraine. E-mail: dreus.a@,dnu.dp.ua 